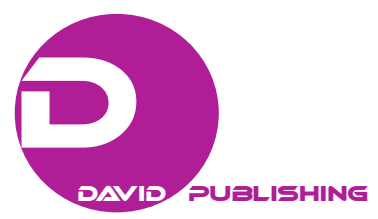

\title{
Quo Vadis? and Other Works by Feliks Nowowiejski in America: History and the Present
}

\author{
Ilona Dulisz \\ University of Warmia and Mazury, Olsztyn, Poland
}

\begin{abstract}
The article discusses the presence of Feliks Nowowiejski's music in American musical culture, particularly among the Polish diaspora, during the composer's lifetime and nowadays. Born in East Prussia and educated in German schools, through contacts with the Polish diaspora, Nowowiejski quickly became an advocate of Polishness in the field of music in Poland and abroad. The paper briefly quotes the scarce sources available which document the performances and reception of Quo Vadis? and the composer's other works overseas, thus complementing our knowledge about the presence of Nowowiejski's music on the other hemisphere of the world.
\end{abstract}

Keywords: Polish music, Feliks Nowowiejski, oratorio Quo Vadis?, American premieres

\section{Introduction}

At the turn of the 19th and 20th century, Poles emigrated on a massive scale to North and South America, mainly to the United States, Brazil, and Argentina. The dynamically developing agglomerations of these countries attracted emigrants from Poland, both at that time and in later years, who travelled across the ocean mainly for economic reasons. Many of those who emigrated after the Second World War recruited from Polish soldiers who fought on the side of the Allies during the war. Prosecuted for political and ethnical reasons, they found shelter overseas. Throughout all these decades, many Polish organisations and institutions were established in North and South America with the aim to preserve Polish traditions and culture abroad. Prominent Poles who became well-known in the Polish communities overseas included, for example, Tadeusz Kościuszko, Casimir Pulaski, Maria Skłodowska-Curie, Fryderyk Chopin, Karol Szymanowski, and Ignacy Jan Paderewski. Feliks Nowowiejski also belonged to this group.

\section{American Debut}

Feliks Nowowiejski (1877-1946) ${ }^{1}$ is one of the few artists who have gained recognition and world fame during their lifetime. He debuted as a composer in the Western hemisphere in 1907. As a young artist and already a recipient of many prestigious awards ${ }^{2}$, he made himself known in the local musical circles,

Ilona Dulisz, Ph.D., Lecturer, Faculty of Art, University of Warmia and Mazury in Olsztyn, Poland.

1 An outstanding Polish composer and organist, a virtuoso, conductor, teacher, initiator of musical life in the interwar period and a great patriot. In his vast and highly diversified output as a composer, comprising over 700 works, are represented nearly all genres and forms of music (instrumental miniatures, songs, motets, hymns, psalms, cantatas, masses, oratorios, operas, ballets, concertos, symphonies, overtures, symphonic poems as well as symphonies and concertos for solo organ-a novelty in Polish music).

${ }^{2}$ For example, as a student of Max Bruch in the School of Masters of Composition at the Royal School of Arts in Berlin he won the First Prize at the G. Meyerbeer competition twice in 1902 and 1904. In 1903, he received the L. van Beethoven Prize funded by I. J. Paderewski. 
particularly among the community of the Polish diaspora, when he won the First Prize at a composers' competition in Chicago for his cantata Piotr Skarga (1536-1612), Op. 18 No. 3 (Fokt, 2017, pp. 70, 362; Nowowiejscy, 1968, p. 66), for male choir, orchestra and organ, written to the words of the Polish poet Lucjan Rydel $^{3}$. The eponymous character of the work was an extremely renowned figure among Polish émigrés. Known as the Preacher of the Polish Nation (the Polish "Bossuet"), Skarga was the author of the highly praised Kazania sejmowe (The Sejm Sermons) and a servant of God. His activity was a proof of his patriotic attitude and prefiguration of Poles' aspirations for independence. It was therefore no coincidence that Nowowiejski chose this renowned figure to be the main theme of his work which he submitted for the competition to Chicago, a city with one of the largest Polish diasporas in the world. Also, in the next year, his cantata Żałobny pochód Kościuszki na Wawel (Kościuszko’s Funeral/Kościuszko's Funeral Cortège to the Wawel), Op. 25 No. 2 for the a cappella choir, another work with a theme close to the Polish diaspora in the USA, won a prize in a composers' competition in Lviv.

The Polish community living abroad played a significant role in shaping the composer's awareness of his nationality and had a substantial impact on his music. Born in Warmia ${ }^{4}$, in the part of Poland which during the Partitions of Poland was taken over by East Prussia, Nowowiejski had a Prussian citizenship and a German birth certificate, and was therefore educated in German schools. However, the love for Poland and the language of his ancestors was instilled into him in his childhood, gradually guiding him towards Polishness. Through contacts with Poles that he got to know during his musical studies in Berlin, he became a great Polish patriot, sincerely dedicated to Poland's struggle for independence and an artist who recognised the well-being of his Homeland as the highest value.

The composer's name started to be recognised in the artistic circles of many European countries, later followed also by North and South America, especially after the premiere of his oratorio Quo Vadis?, Op. 30 for solo voices, choir, and orchestra with organ in Amsterdam, where it was received enthusiastically ${ }^{5}$. The oratorio was performed on 22 October 1909 at the Royal Concertgebouw with Johan Schoonderbeek as the conductor. The composer was present at the concert and was rewarded with endless ovations. As a token of appreciation, he was not only presented with a laurel wreath with sashes (outstanding artists were decorated with the wreaths on the stage in front of the audience), but also with a ring given to him by Queen Wilhelmina of the Netherlands and preserved in the composer's family collection in Poznań until today ${ }^{6}$.

\footnotetext{
${ }^{3}$ The work exists only as a manuscript which is stored in the special collections of the Raczyński Library in Poznań, the composer's hometown. Unfortunately, little is known about the prize itself and the competition.

${ }^{4}$ Historically, Warmia was part of Prussia. By the end of the 13th century, it was conquered by the Teutonic Order. After the Second Peace of Torun in 1466, it was included within the territory of the First Republic of Poland. With the First Partition of Poland in 1772, it was administratively incorporated into the Prussian Kingdom (the province of East Prussia). After the Second World War, it again became part of Poland.

5 Feliks Nowowiejski's Quo Vadis? with a concise libretto written by the Berlin writer A. Jüngst, was based on the well-known novel by H. Sienkiewicz of the same title, published in 1896, for which the author was awarded the Nobel Prize in 1905. The first drafts of the composition were made 1903 during Nowowiejski's artistic travels to the countries of southern Europe and northern Africa.

${ }^{6}$ The composer's house in Poznań, in Al. Wielkopolska 11, known as "The Villa among Roses", nowadays a place of residence of the composer's granddaughter Bogna Nowowiejska-Bielawska and her family, is the seat of the Feliks Nowowiejski Music Salon and Museum. The Maestro's personal items are displayed here along with furniture and works of art that he collected, instruments he played and numerous musical artefacts. Nowadays, the Salon is a place of many artistic and cultural activities. It promotes, amongst others, Nowowiejski's works and serves as an educational facility.
} 
As the distinguished author of the famous oratorio and from 1909 the director of the Music Society in Kraków $^{7}$, in 1910, Nowowiejski was invited to participate in the unveiling of the monuments of Tadeusz Kościuszko and Kazimierz Pułaski (English: Casimir Pulaski) in Washington—symbols of freedom, justice, and the connections of the Polish diaspora in North America with Poland. In addition, the celebrations were combined with the organisation of the first Polish National Congress.

The unveiling of the monument of Tadeusz Kościuszko in Washington along with the monument of [Casimir] Pulaski took place on 12 May 1910, as Wanda Puget writes in the periodical "Ochrona zabytków" [Protection of Monuments]. As many as 5000 Poles from all over the United States were present at the event. It is important that it was a state ceremony attended by President of the United States [William Howard] Taft. A parade was held of American troops and naturally of all Polish organisations together with Bishop Paul P. Rhode (the first Polish bishop in the USA). Attorney Suligowski came all the way from Warsaw and so did Prof. Majerski from Lviv. Former President of the United States Theodore Roosevelt, who at that time was in Europe, issued a special address in writing. A similar letter was also sent by Henryk Sienkiewicz. (Puget, 1994, pp. 202-203)

Nowowiejski joined his compatriots in exile in America spiritually by submitting his personal thank you note for the invitation and a short text on the theme Aforyzm o muzyce (Aphorism about Music), included in a commemorative book devoted to these events ${ }^{8}$. The first part of the book offers a historical outline of the Polish emigration and the Polish diaspora in the US, presenting the history of the erection and unveiling of the said monuments along with the speeches of the eminent figures that attended the event. The second chapter is devoted to the Polish National Congress in Washington, while the third and the last part contains papers, letters, and literary works submitted to the Congress as well as addresses of Polish organisations in Poland and in exile. Nowowiejski's text, dedicated to the music of F. Chopin, was included in the third part in the section entitled Listy od poszczególnych osobistości z ojczyzny, wychodźstwa i obczyzny (Letters from important figures living in the homeland, in emigration and in exile).

Chopin's music, writes the composer, with its sorrowful lyrics is dearer and closer to us, Poles, as he managed to capture in a tone everything that is ours: our pain, our longing, our grief. Amplifying a work of art with the national content is common to our entire artistic output of the 19th century, it is a natural result of the conditions in which we have found ourselves. Even though foreigners accuse our works of art of being too national to be widely appreciated, Chopin did gain recognition of the entire world. How did he do it? He elevated national elements to the universally significant human level, granting them citizenship rights in the pantheon of humanity. This points to the direction in which we should develop our artistic activity if it is to be truly creative rather than be a mere reflection of foreign culture. (Nowowiejski, 1911, pp. 582-583)

\section{Around Quo Vadis?}

On 19 March 1912, less than two years after the Congress, Quo Vadis? had its American premiere in the famous Carnegie Hall ${ }^{9}$. It was conducted by the composer himself who came to New York especially for this

\footnotetext{
${ }^{7}$ F. Nowowiejski held this function until 1914. After the outbreak of the First World War, as the subject of German emperor Wilhelm II, he served in the German army in Berlin.

8 Pamiętnik wzniesienia i odsłonięcia pomników Tadeusza Kościuszki i Kazimierza Pułaskiego: tudzież połaczonego z ta uroczystościq Pierwszego Kongresu Narodowego Polskiego w Waszyngtonie, D.C., stolicy Stanów Zjednoczonych Ameryki Pótnocnej w maju 1910 roku (Diary of the erection and unveiling of the monuments of Tadeusz Kościuszko and Casimir Pulaski and of the First Polish National Congress in Washington, D. C., the capital of the United States of America in May 1910), R. Piątkowski (Ed.), Chicago, 1911.

9 Most sources regard the performance of Quo Vadis? in New York as the American premiere of this work. However, in the advertisement promoting the sale of the score and the libretto of the work, published in the see: Neue Zeitschrift für Musik 1911 from February 23th, p. 123 (advertisement), publisher A. Maier informed about the planned performances of the oratory, among others in Chicago.
} 
occasion. The composer's sons would later recall that the fee for the concert was comparable to that of such world-renowned artists at the time as Enrico Caruso or Ignacy Jan Paderewski. The concert was attended by president of the United States William Taft, Cardinal John M. Farley and outstanding Polish pianist and composer Zygmunt Stojowski (Nowowiejscy, 1968, pp. 90-91). The work was prepared by the choir of the Catholic Oratory Society with the following soloists: Frances Caspari (Lygia), Frederic Weld (Saint Peter) and Gilbert Wilson (the Prefect of the Praetorian Guard), and the New York Symphony Orchestra. However, the praise with which Nowowiejski's sons spoke of how the work was received in New York (Nowowiejscy, 1968, pp. 90-92) does not seem to be confirmed by rather cool and in some cases even sharp reviews in the press (Szatrawski, 2013, pp. 74-81).

In the New York Times, an anonymous critic wrote:

Mr. Nowowiejski has made the first section of his work extremely noisy, very emphatic, employing all the resources of the chorus, orchestra, and organ, and yet with singularly impotent effect: for the mere insistence of noise soon lulls the listener's receptive powers. [...] The choice of this work was not a fortunate one for the Catholic Oratorio Society, although there is no doubt a less ample provision for it to draw from oh modern Catholic choral music than of ancient. (“Quo Vadis?" in choral form: Catholic Oratorio society produces Nowowiejski's work, 1912)

However, let us take a closer look at the work itself. The libretto was written by a German Writter Antonina Jüngst. Quo Vadis? is a monumental oratorio for three solo voices, soprano (Lygia), baritone (Saint Peter), bass (the Prefect of the Praetorian Guard), mixed choir, symphony orchestra, and organ. The composer described it as a collection of dramatic scenes with theatrical and off-stage elements. It addresses a historical and religious problem of a conflict between the Romans under the rule of Emperor Nero and the first Christians. The author of the libretto referred not so much to the actual plot of H. Sienkiewicz's novel but to its background. The action takes place in Rome under the rule of Emperor Nero, 62 years after Christ was born.

The oratorio is divided into four scenes with the final choir part. Quo Vadis? makes a clear distinction between the spheres of sacrum and profanum, which the composer marks by the use of different means of musical expression, in most cases perceptible even to the untrained ear. Their audibility is further supported by the accordingly selected compositional technique that translates into the texture and expression of the piece. Its quasi-leitmotifs as well as illustrative and programme elements are vital components of the work. The character of the first two scenes is primarily secular. The sphere of profanum is achieved with motor-dynamic elements (extreme contrasts; thick, chord-based texture, harmonics—on the one hand, simple; and on the other hand, saturated with colours; illustrative situations, e.g., the March of the Praetorians).

The oratorio's third and fourth scene transfers the listener to the world of persecuted Christians, which is achieved by a definite change in the mood and atmosphere of the composition. Shifting the place of action and the introduction of new characters are signalled by the use of different compositional means. In contrast to the previous parts of the work, here the music becomes more intimate, more chamber-like. The leading role is now no longer played by the choir but by the soloists (Lygia, Saint Peter), the main characters of Quo Vadis? The orchestra in these scenes is more often employed in its reduced form rather than as the entire ensemble. The sound of the organ comes to the fore. The choice of instruments plays an important role, particularly in terms of colours. The content of the work is further accentuated by the manner in which the respective groups of instruments or individual instruments are used, which in most cases is dictated by the value of their sound, thus appearing in the capacity of an illustrative means of expression. In the sound matter, the composer refers to traditional chorale melodies and psalmodic formulas (e.g., the Eucharistic Prayer), and thus to modal harmonics 
and melody, while evoking church singing of the resonsorial and antiphonal type. The score contains such performance directions as: andante religioso or psalmodieren, which clearly define the character of the music.

Nevertheless, the oratorio Quo Vadis? is first and foremost a choral piece. The solo and ensemble parts appear less frequently although they play a significant role in the third and fourth scene. The composer introduces the division into two choirs: Christians and Praetorians. They are characterised by a different texture and different means of expression. The former, for mixed voices, employs a variety of diversified technical means, while the latter, composed mainly of male voices, is characterised by a simple, homorhythmic texture and marching rhythms. The work is crowned with a majestic choral part with a chord-based texture and a monumental double fugue that succeeds it.

The oratorio Quo Vadis? was actively promoted by the publisher of its score, A. Maier of Fulda. He made reprints of the best excerpts from the reviews of the oratorio's performances and concerts published in German and foreign press, which he then included in the subsequent editions of the libretto or released as separate brochures with the list of cities where Quo Vadis? had its premiere ${ }^{10}$. This material allows us to conclude that the piece was performed across North and South America on musical stages in such places and cities as Alastrigt (Brazil) $^{11}$, Baltimore, Boston, Cincinnati, Chicago, Philadelphia, Indianapolis, New York, San Francisco, Springfield, St. Louis, and Toronto.

Apart from the premiere in New York, little is known about the other American performances of the piece in the cities listed by Maier. A piano excerpt from the work was published in the English version (translated by Grace Hall) in 1914 by one of the oldest American classical music publishing companies, G. Schirmer, Inc. based in New York, with branches in Boston and London, which shows that the work must have evoked a lot of interest in North America. Nowowiejski's oratorio was also submitted to many American libraries. For example, its two German editions, the score and a piano excerpt (A. Maier Verlag, 1909), and a New York edition (G. Schirmer, Inc., 1914) were included in the catalogue of the Boston Public Library as early as in $1916^{12}$.

As far as the history of the performances of Quo Vadis? is concerned, we know of one more premiere which Maier did not mention in his list. It took place on 11 March 1923 in the Los Angeles Philharmonic Auditorium, where the work was performed by the Los Angeles Oratorio Society and Los Angeles Philharmonic Orchestra with the local soloists: Monnie Hayes Hastings-soprano, Carl Gantvoort-baritone, and Clifford Lott-baritone. The piece was very well received and it was repeated two seasons later with the famous baritone Joseph Swartz as Saint Peter (Smallman, 1933, p. 77).

\section{Other Works}

Nowowiejski's other works were also present in the programmes of American concerts and recitals. Although today it is difficult to verify what the reception of the composer's music in the American musical circles was at the time, a few facts may be established based on preserved musical catalogues, press articles, and programmes.

\footnotetext{
10 The exact dates of the publication of these brochures cannot be determined. The author of the article managed to obtain access to two leaflets of this kind which were probably released around 1915 and 1930. The first of them contains additional information provided next to the name of the city of San Francisco: "The 1915 World Exhibition". The second offers a note informing about the performances of Nowowiejski's oratorio planned for 1930 .

${ }^{11}$ It is impossible to establish the name of this town today. It might have become a part of a larger city.

12 See Catalogue Allen A. Brown Collection of Music in the Public Library of the City of Boston, Boston 1916, Vol. IV Suplement, p. 273.
} 
The 1908 catalogue of the Library of Congress includes a list of compositions protected under the copyright and lists the following of Nowowiejski's compositions as originating from the German culture:

- Im lenkbaren Luftschiff. Marsch des Luftschiffer-Bataillons (In a Steerable Airship. March of the Airship Battalion) (Heinrichshofen's Verlag, Magdeburg, 1907), a version for piano;

- Heimweh (Homesick), Op. 26 (Alois Maier Verlag, Fulda, 1908), to the words by Margarete Bruch, for solo voice and piano;

- Heil'ge Stunde, wann aufs stille Meer op. 35 (How dear to me the hour wehn daylight dies), Irish song to the words by Th. Moore, translated by P. L. van Fürstenberg, for solo voice and piano (Alois Maier Verlag, Fulda, 1908);

- Der Schmied von Barlt (A Smith of Barlt) to a text by M. Geissler, released also in 1908 by August Scherl $\mathrm{GmbH}$ in Berlin for solo voice and piano (August Scherl G.m.b.H., Berlin, 1908) ${ }^{13}$.

In turn, the 1912 catalogues of the Library of Congress included very popular and highly praised pieces by Nowowiejski, such as the overture for symphony orchestra Swaty Polskie (Polnische Brautwerbung) (Polish Matchmakers), based on themes from Polish folk melodies (J. Schuberth, Leipzig, 1903) ${ }^{14}$, and Slavic Folk-Scene, Op. 18 (title in the original: Kujawiak) to the text by M. Konopnicka, translated into German by M. Pick, a score for choir and orchestra (Ed. Bote \& G. Bock, Berlin, 1912) ${ }^{15}$. The latter was performed for example during the Ninth Annual Music Festival, which took place at Cornell University between 30 April and 2 May 1914. Nowowiejski was listed in the concert programme next to such composers as E. d'Albert, F. Mendelssohn, J. Massenet, C. Saint-Saens, and R. Strauss. The programme included a short description of his piece and the English translation of the text by J. E. Middleton. Furthermore, the journal Musical Canada from 1916 and 1917 informed about the performances of Nowowiejski's Christmas fantasies for solo organ in Hamilton by W. H. Hawlett, the Organist and Choirmaster of the Centenary Methodist Church ${ }^{16}$. The composer's choral songs, both patriotic and religious, as well as his settings of folk songs were also popular among the Polish diaspora. The libraries offered, amongst others, the songbook Zjednoczona Polska (United Poland), Op. 38 (Poznań, 1921; 1924; 1928; 1931) and the collection Śpiewnik szkolny. 12 kanonów polskich (A school songbook. 12 Polish Canons), Op. 23 No. 1 (Warsaw, 1932). Also, Three Motets, Op. 5 No. 1 for mixed choir were published in New York (J. Fischer \& Bro., 1912), while the collection The Parish Hymnal by Joseph Otten ${ }^{17}$ included one of Nowowiejski's songs entitled International Eucharistic Hymn, composed to the words by the composer's brother-Father Rudolf Nowowiejski.

\section{In Memoriam}

Another important testimony to the constant presence of the composer's music overseas, particularly among the Polish diaspora in North America, were the words of Tadeusz Zygfryd Kassern ${ }^{18}$, the cultural attaché of the Polish consulate in New York, addressed to the widow of Feliks Nowowiejski in a condolence

\footnotetext{
13 See Library of Congress, Catalogue of Copyright Entries, Part 3: Musical Compositions Volume Index, Washington 1908, pp. $165,486,514,611$.

14 See Library of Congress, Orchestral Music Catalogue, scores, prepared under the direction of Oscar George Theodore Sonneck, Washington 1912, p. 325.

15 See Library of Congress, Catalogue of Copyright Entries, Part 3: Musical Compositions, New Series, Vol. 6, Part, Washington 1912, s. 876.

16 See "Musical Canada" 1916, Issue XI No. 1, p. 137; "Musical Canada" 1916, Issue XII No. 1, p. 154.

17 Organist and Choirmaster of St. Paul`s Cathedral in Pittsburgh, Pennsylvania.

18 A composer, music critic and a lawyer, in 1922-1939 associated with Poznań, an admirer of Feliks Nowowiejski's music.
} 
letter of 20 February 1946. Shocked by the Maestros' death, the information about which was published in the American press (including the New York Times), Kassern assured her that the composer's music had lived and still continued to live in America, and he expressed his desire to celebrate and further popularise Nowowiejski's works in American musical circles ${ }^{19}$. Information about the composer's passing was also published in The Slavonic and East European Review, which read: "With the death in Poznań of Feliks Nowowiejski, modern music, in particular sacred music, has lost a distinguished master" (W. J. R., 1946, p. 251).

The memory of Feliks Nowowiejski was revived particularly in the years 2016-2017, when Poland celebrated the 70th anniversary of the composer's death and the 140th anniversary of his birth. On this occasion, the Polish government allocated significant subsidies for the promotion of the composer's output. In August 2016, the Chamber Choir of the Feliks Nowowiejski Academy of Music in Bydgoszcz went to the US (Lemont, Chicago, and New York) to present the composer's works as part of the celebrations programme. During the tour, the ensemble gave 13 concerts under the direction of Janusz Stanecki. Their programme included Nowowiejski's patriotic, religious, and folk songs as well as major vocal and instrumental works "Ojczyzna" Psalm 136 (“Jerusalem") ("Homeland" Psalm 136 ["Jerusalem"]), Op. 18 and Missa pro pace, Op. 49 No. 3 for choir and organ, as well as organ pieces performed by Jakub Kwintal. The concerts were accompanied by lectures presenting the life and works of Feliks Nowowiejski ${ }^{20}$.

\section{Conclusion}

This analysis of the presence of Feliks Nowowiejski's works in the American musical life, based on the source materials obtained by the author, indicates that the composer's music has been known there, especially among the Polish diaspora, for over 100 years. His works, particularly those originating from Polish history, culture, and tradition, have deeply moved the listeners overseas and so did his religious compositions. From early on the Polish community in America accepted the composer and his music with great enthusiasm, as it is evidenced for example by Nowowiejski winning the First Prize in a composers' competition in Chicago in 1907, by the performance of Quo Vadis? in 1912 in Carnegie Hall in New York with Nowowiejski as the conductor and by the presence of the composer's pieces in the catalogues of the Library of Congress in Washington, the most prominent institution of this kind in the world. Contemporary concerts are also a proof that the memory of the composer and his music lives on.

\section{References}

Fokt, I. (2017). Feliks Nowowiejski. Poznań: Towarzystwo im. Feliksa Nowowiejskiego, Akademia Muzyczna im. I.J. Paderewskiego.

Nowowiejscy, F. M. K. (1968). Dookoła kompozytora. Wspomnienia o ojcu (Around the composer. Memories about the Father). Poznań: Wydawnictwo Poznańskie.

Nowowiejski, F. (1911). Aforyzm o muzyce (Aphorism about Music). In R. Piątkowski, (Ed), Pamiętnik wzniesienia i odstonięcia pomników Tadeusza Kościuszki i Kazimierza Pułaskiego: tudzież połaczonego z ta uroczystościq Pierwszego Kongresu Narodowego Polskiego w Waszyngtonie, D.C., stolicy Stanów Zjednoczonych Ameryki Pólnocnej w maju 1910 roku (Diary of the erection and unveiling of the monuments of Tadeusz Kościuszko and Casimir Pulaski and of the First Polish National Congress in Washington, D.C., the capital of the United States of America in May 1910) (pp. 582-583). Chicago: Nakładem Związku Narodowego Polskiego w Północnej Ameryce.

\footnotetext{
19 The condolences are available (in Polish) at: cyryl.poznan.pl, collection name: Feliks Nowowiejski-funeral and condolences, 1946, Archive of the Nowowiejski family, accessed on 15 August 2018.

20 See: http://www.amuz.bydgoszcz.pl/rok-feliksa-nowowiejskiego-promocyjny-sukces-uczelni-na-terenie-usa-13-koncertowchoru-kameralnego-am-w-chicago-lemont-nowym-jorku-i-waszyngtonie/, accessed on 12 August 2017.
} 
Puget, W. (1994). Pomnik Tadeusza Kościuszki w Waszyngtonie (The Tadeusz Kosciuszko Monument in Washington). Ochrona zabytków (Protection of monuments), 47(2), 202-203.

"Quo Vadis?" in choral form: Catholic Oratorio society produces Nowowiejski's work. (1912). The New York Times, March 20 th. Smallman, J. (1933). Los Angeles Oratorio Society. A Record of Musical Community Progress. In B. D. Ussher (Ed.), Who's who in music and dance in Southern California (pp. 76-78). Hollywood: Bureau of Musical Research/William J. Perlman Publisher.

Szatrawski, K. D. (2013). Popularny i niedoceniony-wokół amerykańskiego debiutu Feliksa Nowowiejskiego (Popular and unappreciated - around the American debut of Feliks Nowowiejski). In K. D. Szatrawski (Ed.), Od pieśni do symfonii. Artystyczne i społeczne konteksty twórczości Feliksa Nowowiejskiego (From song to symphony. Artistic and social contexts of the works of Feliks Nowowiejski) (pp. 71-88). Barczewo: Stowarzyszenie Inicjatyw Obywatelskich.

W. J. R. (1946). Feliks Nowowiejski. The Slavonic and East European Review, 25(64), 250-251. 